\title{
International Social Law for an International Solidarity Community ${ }^{* * *}$
}

\section{Direito social internacional por uma comunidade solidária internacional}

\author{
Guilherme Camargo Massaú ${ }^{* *}$ \\ Lieben Freunde, es gab schönre Zeiten \\ Als die unsern - das ist nicht zu streiten! \\ (Schiller - An die Freunde - 1802)
}

\section{Abstract}

This paper aims to establish a common ground for solidarity requirements at the international level, in special between Brazil and the European Union. This essay departs from an initial international solidarity assumption, i.e., the common idea of human dignity both in international statements and in State constitutions, as well as from rules of Community law. As to restrictions, the paper is based on the European Community law and the Brazilian constitution, and thereby discusses a common element worthy of legislative protection, which is the human being rather than the citizen. Thus, both in Community and in Brazilian law, one's foreign, native or community condition should not interfere with the human being access to social rights. Therefore, by defending the respective regulatory scopes, such dimensions are committed to promoting human dignity in terms of social rights, in solidarity with the human condition itself, in whatever it requires. The study made use of the deductive method, once it is developed

Title adapted from the article (Soziales Völkerrechts für eine solidarische Völkergemeinschaft?) by Prof. Markus Kotzur PhD, published in Juristen Zeitung, 6, 63. Jahrgang, 21 März 2008. p. 265316.

* I thank my friend Leonardo Camargo Subtil, Doctor in Law from the Federal University of Rio Grande do Sul, Brazil, and a doctoral student in Droit International Unige at the Université de Geneve for the advice and contributions to this study.

*** Doutor em Direito pela Universidade do Vale do Rio dos Sinos - Unisinos; Mestre em Ciências Jurídico-Filosóficas pela Universidade de Coimbra. Professor da Faculdade de Direito e do Mestrado em Direito da Universidade Federal de Pelotas - UFPel. Pelotas - RS - Brasil. E-mail: uassam@gmail.com. 
from general premises in order to find an answer to a specific situation, that of the international solidarity between Brazil and the European Union. The text included a literature review and consultation to legislative documents.

Keywords: Brazilian Constitution. Human Dignity. Social Rights. Solidarity. European Union.

\section{Resumo}

O texto tem por objetivo estabelecer um denominador comum para a exigência de solidariedade no âmbito internacional, principalmente entre o Brasil e a União Europeia. Contudo, trata-se de um ensaio que aponta um primeiro pressuposto para a solidareidade internacional, a ideia comum de dignidade humana, tanto em declarações internacionais quanto nas constituções dos Estados, e, também, nas normas de direito comunitário. Em termos de restrição, o texto baseia-se no direito comunitário europeu e na constituição brasileira, e, com isso, aponto o elemento comum merecedor de proteção normativa, que é o ser humano, e não o cidadão. Dessa forma, tanto no direito comunitário quanto no direito brasileiro, para ter acesso aos direitos sociais básicos de um ser humano, não importa se estrangeiro, nacional ou comunitário. Por conseguinte, no sentido da defesa dos respectivos âmbitos normativos, tais dimensões têm o compromisso de promover a dignidade humana em termos de direitos sociais, solidarizandose com a própria condição humana, naquilo que ela exige. O texto empregou o método dedutivo, pois partiu de premissas genéricas para encontrar respostas para determinada situação, a da solidariedade internacional entre Brasil e União Europeia. O texto foi composto por meio de pesquisa bibliográfica e de consulta a documentos legislativos.

Palavras-chave: Constituição brasileira. Dignidade Humana. Direitos sociais. Solidariedade. União Europeia.

\section{Introduction}

This study aims to find a normative interpretation on how to improve the relationship between Brazil (a unitary State) and the European Union so as to optimize social rights at an international level. In this sense, the thoughts herein formulated will serve as a basis for reflection on other issues to be analyzed in the future. This work reflects on a scenario that supports the pursuit of a legal image for an eventual international social 
law from a solidarische Volkergemeinschaft view. The study is supported by references to international norms and the reality of international law regarding State sovereignty.

The world historical experience, especially after the two world wars, led nations to expand their guarantees and protections to the human being, relying on law as a delimiting normative mechanism of what is worthy or unworthy to man ${ }^{1}$. Several international declarations and treaties, as well as numerous constitutions (MARQUES, 2010, p. 546-557) of States, have been organized to promote the idea of human dignity $^{2}$. Thus, valid and effective fundamental rights and human rights, are made available where fundamental rights have an internal validity to each State, and human rights have international validity in relation to the States and among signatory States of treaties, in addition to those States which are supported and guided by declarations, customs, general principles of law and resolutions from international organizations (COMPARATO, 2001, p. 227).

Consequently, a protection condition for the human being and his dignity was established because, independently of having or not a homeland, the fact of being human itself grants the individual a State and international legal protection in terms of objective law, with repercussions on subjective law $^{3}$ This results from the expansion of international

1 This text aims to establish the foundations for the analysis of other issues regarding the principle of solidarity and the realization of social rights at an international level. An example of this is a possible and necessary provision of a procedural mechanism on which people could rely in fundamental and human rights violation allegations, and the establishment of international law norms among States as well as a duty of solidarity among nations as to social rights. Another issue to be developed is a normative classification of social rights when addressing international solidarity.

2 Human dignity has a dual function: a) it represents a subjective-legal situation, and is a constitutional and international principle of all rights related to the development of the person and his social relations; b) it expresses a principle of legal organization to be pursued by the social and political systems. (APOSTOLI, 2012, p. 38).

3 Note that the subjective law standpoint will be the focus of another paper, where a procedural mechanism through which the individual can claim respect for human rights that have been violated by the State or community which he is foreign to or native of will be proposed. 
relations and the opening of the States to a global legal value order ${ }^{4}$ to man, the main element of the world community ${ }^{5}$, (MARTINO, 2010, p. 342). For this reason, contemporary constitutionalism has multi-level and pluralistic contours so that an openness to regional and international realities - not only political and economical, but also social - can be established. It is a process of trans-nationalization of a growing legal order (KOTZUR; SCHMALENBACH, 2014, p. 69) that encompasses both regional and global jurisdictions of international institutions with regard to, in the context of this paper, fundamental and human rights violations (NETTO, 2010, p. 129).

In addition to its normative promotion, human dignity needs to be minimally protected. For such, the realization of fundamental human rights is an essential condition. Both negative as well as positive freedom rights are prerequisites for attaining human dignity. This text covers, in general terms, the normativity of the principle of solidarity in the realization of social rights in the International Law Context, though restricted to the relationship between Brazil and the European Union. Thus, a dimension of International social rights of both internal and external effectiveness to the State, including, in theory, all human beings, without distinction of origin, is sought.

For such, three hypotheses are proposed: 1) situations where social rights are not provided by a sovereign State to its citizens; 2) situations where third country or stateless individuals are not provided by a sovereign State; 3 ) situations of solidarity among sovereign states

4 In general introductory terms, it is necessary to highlight the moral requirement that can be found in the United Nations (UN) Charter, a common norm, since the States that have signed the UN Charter have also adhered, both externally and internally, to its principles and values. Some aspects need to be highlighted, such as the undemocratic character of the Security Council through the power of veto and life members, the fact that the UN Charter is not hierarchically superior to other rules, the binding effect of the UN Charter and connections with third States that have not adhered to it. (MARTINO, 2010, p. 343-344; COMPARATO, 2001, p. 226-227).

5 Despite the theoretical and conceptual difference between the meanings of the words community and society, they are employed here as conceptual synonyms in order to develop the proposed theme within 30 pages at most. 
towards international cooperation (KOTZUR; SCHMALENBACH, 2014, p. 68-70) ${ }^{6}$. As for the analysis of the first hypothesis, solidarity depends on conditions which relativize the transgressor State sovereignty ${ }^{7}$. With reference to the second hypothesis, solidarity imposes itself as a duty to provide social rights in which the no-provider State is a member of the international community and, as such, is committed to carry out fundamental human rights, more specifically, social rights. The third hypothesis refers to the mutual aid that the international community should provide for its fellow countries in case of need, emergency and other complex circumstances which are too complex to be tackled by a State alone (KOTZUR; SCHMALENBACH, 2014, p. 69, 75-78). The first and third hypotheses will not be the object of this analysis, which will rather focus on the second one.

The second hypothesis was chosen for being the most complex and rich in utopian elements ${ }^{8}$. This is a hypothesis that impacts, e.g. the lives of immigrants who currently come to Europe in search of new living conditions. (HONDRICH; KOCH-ARZBERGER, 1992, p. 100-105; STRENGER, 2006, p. 983). It also refers to a situation in which several social rights guarantees are not extended to the immigrant with reference to a minimum existencial support, as compared to those held by a citizen. In this sense, a solidarity that can be inferred from the Brazilian and European realities will be addressed, inasmuch as commitment correlations of human beings between these two international realities, regardless of the Brazilian or European citizen qualities, are to be established ${ }^{9}$.

Solidarity among sovereign States will be the object of another analysis.

An example of this was the the Provisional Measure imposed by the Inter-American Court of Human Rights to Brazil in March 2014 because of the country's violation of human rights of people under criminal custody by the State (prisoners) at a penitentiary in the state of Maranhão. InterAmerican Court of Human Rights. Resolution of 22 May 2014. <http://www.corteidh.or.cr/docs/ medidas/curado_se_01_por.pdf>. Site visited on 15/11/2015.

8 The term utopian elements refers to the goals that the international community seeks to achieve, but which are nonetheless still far from being accomplished, whether for political, economic, social or even legal issues.

9 This expression is used to indicate the origin of the individual in Brazil, as is the case of this text, to whom a legal European citizenship is still unavailable. 
The following points will be addressed to achieve our goals: for the normative implementation of the principle of solidarity, the normative character of solidarity will be sought in order to to establish its legal characteristics; fundamental and human rights both in Brazil and in the European Union will be marked out to establish the equality of intersection points regarding human rights effectiveness in relation to human beings. The topic referring to the Brazilian constitutional openness to international social rights seeks to establish how the Brazilian Federal Constitution absorbs norms of international hue, thus creating an open space for international legal influences. The next topic proposes the legal possibility of a normative compromise between Brazil (a sovereign State) and the European Union (EU) (a regional community of sovereign States) with respect to social rights, as an interpretive essay. The penultimate topic has the purpose of establishing a legal-evaluative consensus and demonstrate that both the EU and Brazil are at least normatively oriented towards the same goal of promoting human dignity through human and fundamental rights. Finally, among several other possibilities, a normative application with respect to International Law between two distinct realities in the international scenary, i.e. between Brazil and the European Union, is proposed.

\section{Normative realizations of the principle of solidarity}

Art. I of the Universal Declaration of Human Rights (ORGANIZAÇÃO DAS NAÇÕES UNIDAS. Declaração Universal dos Direitos Humanos) considers a social life which allows human beings to share freedom, dignity and equality of rights to be the first and fundamental characteristic of man. This article also determines that community organization be based on the principle of proportional or distributive justice. This is so because distributive justice takes into account an essential equality of human beings, who are thought to be more important than the economic value (COMPARATO, 2001, p. 462). This view is reflected in declarations, customs, resolutions and treaties referring to Human Rights, especially those in vogue in Europe and the Americas: Preamble, Arts. 27 to 38 of 
the Charter of Human Rights of the European Union (UNIÃO EUROPEIA. Carta dos Direitos Fundamentais da União Europeia); Art. 26 of the American Convention on Human Rights. (CONVENÇÃO AMERICANA SOBRE DIREITOS HUMANOS).

The importance of solidarity (PIAZOLO, 2004, p. 133-134), which is the very expression of living in community without losing one's individuality by means of cooperation and mutual assistance, is discussed in Articles 1, 3 and 4 of the UN Charter. (CARTA DAS NAÇÕES UNIDAS). In this sense, there is diversity among Men who have an identity and pursue a common goal (ZOLL, 2000, p. 13-14; DEPENHEUER, 2011, p. 666). Without solidarity there would not be a common social aggregation dynamics, whose legal responsibility is to promote the common good and social justice through a democratic process (SOMMERMAN, 2014, p. 10; SCHOLZ, 2014, p. 50; ZOLL, 2000, p. 74-75). This solidarity is accentuated and universalized (ZOLL, 2000, p. 174) insofar as the problems to be faced are not restricted to the State, but also to other States and the international community.

Solidarity is inserted into a normative social order-ubijus ibi societas - specifically organized by Law (HÖFFE, 2005, p. 103; APOSTOLI, 2012, p. 5-53; GIUFFRĖ, 2002, p. 13-20; HONDRICH; KOCH-ARZBERGER, 1992, p. 11). It is evidenced by social welfare requirements of a State which originate economic and administrative measures of social impact of direct intervention based on a complex system of social benefits at all levels in order to pursue individual and social progress, thus reducing economic and social barriers that restrict freedom and equality for the the purpose of overcoming inequality, discrimination and promoting integration (APOSTOLI, 2012, p. 2, 9; 41) among national citizens and between national and foreign citizens, a co-responsibility for carrying out common values and goals, thus becoming a social fact (GIUFFRË, 2002, p. 11; SOMMERMANN, 2014, p. 10-11;13; ZOLL, 2000, p. 17; DEPENHEUER, 2011, p. 673).

Solidarity is convened in a decisive way because it is meant for a concrete Man, a member of society, not an abstract or isolated being. 
Thus, solidarity derives duties to other Men and society, including the prospect of essentially subjective social situations.It embodies the concept of substantive equality (Art. II of the Universal Declaration of Human Rights) (COMPARATO, 2001, p. 229; ORGANIZAÇÃO DAS NAÇÕES UNIDAS. Declaração Universal dos Direitos Humanos) and establishes an integration-duty bond among people in society (APOSTOLI, 2012, p. 10; GIUFFRĖ, 2002, p. 57). Therefore, solidarity makes people's freedoms adjust to one another under a minimum goal of social justice (ANDRADE, 1987, p. 49-52; 86; GIUFFRE, 2002, p. $18-19 ; 21)$. The principle of solidarity operates through social cohesion, involving all subjects who somehow participate in the sphere of relations, which can be either local, national, regional or global. (APOSTOLI, 2012, p. 11). The differences among people who interact through solidarity (HONDRICH; KOCH-ARZBERGER, 1992, p. 13) reveals the open and pluralistic character of the solidarity link; due to this fact, there may be different solidarity scopes and intensities ${ }^{11}$.

Some of the characteristics included in solidarity definitions, such as positive affection, love of neighbor, moral obligation and self-interest (STOLZ, 2014, p. 116) are not included in the core of the concept of solidarity in the legal field. The main element shall be the obligation to be in solidarity as a result of living (together) and interacting with one another, i.e. in society (whether national, regional or global) (KOTZUR; SCHMALENBACH, 2014, p. 71). It is the recognition of the assumption that, in order to accomplish fundamental rights and human rights, all human beings must be responsible, which requires solidarity value and action (ANDRADE, 1987, p. 146; GIUFFRĖ, 2002, p. 61; DEPENHEUER, 2011 , p. 669). Therefore, the State uses its power to transform solidarity into a social phenomenon (SOMMERMANN, 2014, p. 14).

This is a move that gives a sense of self-worth to the universalization of a free and dignified human existence, seeking to reduce material 11 To be discussed in another article. (APOSTOLI, 2012, p. 24-25, 64-67; 106; GIUFFRĖ, 2002, p.
72-74; 282). 
inequalities rather than restrict formal equality (GIUFFRE, 2002, p. 85; KOTZUR; SCHMALENBACH, 2014, p. 74). This implies carrying out public services and recognizing social interdependence among participating individuals in a society, or before a Sate or union of States (SOMMERMANN, 2014, p. 14-15) (whatever scope this interdependence may have). However, reducing material inequalities does not mean reducing differences that line up the ethnic and cultural richness of human beings, but rather recognizing the existing plurality in social circles based on the peculiarities of each person's individualities. Therefore, solidarity must also operate amidst cultural differences and equality of being a human beingAccordingly, attention must be paid to the plurally complex realities of Brazil and the European Union. (ZOLL, 2000, p. 170-172; PIAZOLO, 2004, p. 60-63).

\section{2a On Brazil}

The concept of solidarity implies a concrete human being who is the accountability center of realization, together with the State, fundamental rights, human rights and social duties in the pursuit of freedom and equality to all socii (GIUFFRÈ, 2002, p. 26). This is not just restricted to citizens, but involves all human beings, including foreigners who come from another culture who, in spite of being different, are equal because they are all human. This relationship between difference and equality is also one of the foundations of solidarity (ZOLL, 2000, p. 165166). However, such a basis is a problem to be faced in terms of the recognition of social rights among different citizenships.

Solidarity is provided in fine in Art. 3, I of the Brazilian Constitution. Such constitutional provision is called a transformative clause (BERCOVICI, 2005, p. 36-37), inasmuch as it sets goals to be achieved by the Brazilian society. The aim of item I of Art. 3 of the Federal Constitution is to build a free, fair and solidary society. Here, the principle of solidarity is explicit in the Federal Constitution. Solidarity is also implicit in Welfare State devices, such as social assistance and social rights. Thus, pursuant to Art. 5, caput, of the Federal Constitution, 
fundamental rights are extended to all foreigners living in Brazil ${ }^{12}$. In this case, the social solidarity (SOMMERMANN, 2014, p. 19) sought by the constitutional rule is to be extended to foreigners, which also occurs with universalization (e.g. Art. 196 of the Federal Constitution) of some access dimensions to essential public services of social rights realization.

\section{2b On the European Union}

In continental Europe the idea of solidarity is part of a cultural tradition and policy based on the identity of a community that corresponds to the "people of Europe." This idea was consolidated after World War II in various areas, such as economics, politics, culture and the circulation of 'people to achieve unity of the European peoples. Therefore, several passages of European legal rules invoke solidarity, so that the European Union can in fact be fully realized (PIAZOLO, 2004, p. 210-216).

European Union (EU) integration is based on common interest and its institutions assist one another, seeking a de facto solidarity. Solidarity is recognized as a general principle (Art. 2 EUT) (KOTZUR; SCHMALENBACH, 2014, p. 72; PIAZOLO, 2004, p. 207-210; UNIÃO EUROPEIA. Tratado da União Europeia (versão consolidada) to the extent that its deductive unfolding into other legal principles generates obligations to member States (Art. 21 EUT). (UNIÃO EUROPEIA. Tratado da União Europeia, versão consolidada). One can mention mutual solidarity among EU members (Arts. 24 and 32 EUT) (UNIÃO EUROPEIA. Tratado da União Europeia, versão consolidada). and social solidarity involving the so-called European citizens and member States (Arts. 27 to 38 of the Charter of Fundamental Rights of the European Union) (UNIÃO EUROPEIA. Carta dos Direitos Fundamentais da União Europeia) as well as principles related to that of solidarity, such as loyalty among member States (Art. 4, 3 EUT) (UNIÃO EUROPEIA. Tratado da União Europeia, versão consolidada) and the principle of subsidiarity (Art. 5, 3, EUT). (SOMMERMANN, 2014, p. 19-23; HONDRICH; KOCH-

\footnotetext{
12 This issue will be further developed in topic 2.1.
} 
ARZBERGER, 1992, p. 12; UNIÃO EUROPEIA. Tratado da União Europeia (versão consolidada).

A clear manifestation of solidarity in the EU refers to the rules governing cooperation among States at different levels, e.g. a system of prevention, protection and cooperation against disasters. (KOTZUR; SCHMALENBACH, 2014, p. 78-80). Without it, the idea of union or community loses its existing condition, as it depends on the interaction among parts to form a minimally uniform whole. The interaction among members of the EU takes place through cooperation. While there may be differences and conflicts, solidarity must prevail so that a complex community such as the European can be not only maintained but also further developed.

Thus, broadly speaking, solidarity in the constitutional and community law as well as international law scope is directed towards public actions of social rights realization, whose political community (involving State, national and international private social organizations, the EU and international agencies such as those linked to the UN) ${ }^{13}$ generates, implements and develops institutionalized protection in the economic and social contexts (CANOTILHO, 2002, p. 511-512). But solidarity cannot be reduced to a corrective element to balance the inequality produced by an economic system of individualistic market and neither can it be considered an enforcement instrument guaranteeing government legitimacy as a social order foundation (GIUFFRË, 2002, p. 132; HONDRICH; KOCH-ARZBERGER,1992, p. 24-25). The use of other mechanisms to achieve common good is necessary.

\subsection{Fundamental rights and human social rights}

The foundation of social rights (or positive freedom rights) is encountered in the human nature of being-with-others of Aristoteles' zoon politikon (ARISTOTELES, 2010, p. 46-47; PIAZOLO, 2004, p. 37-38; 5013 This is referred to in the Universal Declaration of Human Rights Arts. XXII to XXVI. Such articles
express the principle of solidarity in the form of social rights. (COMPARATO, 2001, p. 230). 
51), and in the cooperative action demanded by the human condition. This refers to the interdependence of a concrete, circumstantial and interest-bearing man rather than an abstract one out of his historical reality (ANDRADE, 1987, p. 23; APOSTOLI, 2012, p. 18; PISANÒ, 2011, p. 171-172). Thus, the individual does not suffice himself and his existence makes sense from the understanding of the community that surrounds him. Therefore, social rights within the State (the political community), unlike negative rights of freedom, require phatic provision from the State entity (RÜFNER, s.d., p. 590; SARLET, 1998, p. 185190-191). Nevertheless, two points for the realization of social rights must be highlighted: a) positive State action requires, in many cases, bulky financial resources to meet demand requirements; b) constitutional standards of social rights require, in some cases, the enactment of additional legislation by the legislator (RÜFNER, s.d., p. 591-592).

Thereby, there are two issues that relativize the immediate application of some Social rights, though the State (or States) must constitutionally ensure an existential minimum (APOSTOLI, 2012, p. 142) to any human being through solidarity, or else the principles of human dignity, effectiveness of fundamental rights and respect for human rights will be broken ${ }^{14}$. It is also relevant to mention that social rights are linked to negative rights of freedom insofar as rights of freedom become effective according to social rights fruition (HÖFFE, 2005, p. 7981; GIUFFRE, 2002, p. 112). Freedom is consolidated through the State and not before the State (SARLET, 1998, p. 49; 185).

Social rights are one of several essential conditions for the acquisition and maintenance of human being dignity. This is due to the fact that basic social services are sine qua non conditions for the worthy existence of Man and, therefore, the effectiveness of any of his rights (CANOTILHO, 2002, p. 18-19;APOSTOLI, 2012, p. 18-19). They are indispensable subsidies to Man's survival and his ability to act responsibly (HÖFFE, 2005, p. 84). The legal system (whether national, regional or

14 Although solidarity as a human right and fundamental right will be topic of another article, also see:
Scholz (2014, p. 52-53). 
global) which is committed to human dignity should promote the minimum effectiveness of social rights, either through the establishment of legal and constitutional guarantees, complementary legislation or by selfapplicable constitutional regulations (RÜFNER, s.d., p. 594). However, even in the absence of these conditions, the legal condition of promoting human dignity in conjunction with a normative provision of social rights must be self-applicable to the point of ensuring an existential minimum.

At a State level, guarantees of social rights effectiveness are ensured for citizens or persons recognized by the State. This issue becomes politically and legally more complex when applied to people who are not entitled to social rights effectiveness in a particular State. Such being the case, legal positions of universal and permanent rights should prevail to all human beings, independently of their temporal and spatial conditions. However, some fundamental rights are specific and restricted exclusively to citizens or those to whom the State acknowledges such prerogatives. Such restrictions cannot violate the idea of an existential minimum, which in this case would have universal validity, without including any legal and political categories of the individual. The same applies to certain social groups (e.g. workers, the disabled, children, the elderly). This does not refer to class privilege, but rather to effectively achieving equality in different social situations (ANDRADE, 1987, p. 184186).

Accordingly, it is necessary to eliminate the contradiction of human rights being considered universal and inalienable and simultaneously being only protected by sovereign States which, because of their sovereignty, do not recognize anything superior to themselves and consider human rights as national rights to be protected and privilege their citizens. (KOTZUR; SCHMALENBACH, 2014, p. 89). Thus, the relationship between the State and the citizen is established. However, with the universalization of human rights and the international human rights commitment, the State cannot reduce and ensure such privileges to its citizens alone. It is essential that the right to have rights belong to humanity (Art. VI of the Universal Declaration of Human Rights ORGANIZAÇÃO DAS NAÇÕES UNIDAS. Declaração Universal dos 
Direitos Humanos), i.e. it must be guaranteed by and for mankind. The understanding that international law is based on mutual agreements and treaties among sovereign States and that their compliance depends exclusively on the signing State (ARENDT, 1989, p. 262 and 332) will need to be improved. In legal terms, it is a mandatory rule.

The tendency to transcend State sovereignty regarding the protection of human rights gained prominence after World War II (COMPARATO, 2001, p. 54-55; 226; MARTINO, 2010, p. 265; PIAZOLO, 2004, p. 134-137). Human rights conventions try to go beyond specific interests of States so as to create collective guarantees and objective obligations to preserve international public order. Thus, international law seeks to protect the rights of non-citizens by safeguards and international guarantees (LAFER, 1988, p. 154-155). This is not about prevalence the International Law rule over domestic law rule, but an act of recognition, both at international, national and local levels - of the essential character that fundamental rights and human rights hold, in which the most beneficial rule to the human being (COMPARATO, 2001, p. 59-60), rather than the citizen alone, prevails.

Beyond the monistic and dualistic theories, after World War II, in addition to the signing of various international covenants and treaties on human rights, numerous constitutions adopted the same values in their normative provisions (COMPARATO, 2001, p. 59), i.e. basically the same human rights ensured under international covenants and treaties. Thus, there was conformity between international and national law. It is necessary to acknowledge and enforce human rights provisions for non-citizens within each State through the application of fundamental rights. However, this does not occur selectively by means of political and legal categories of human beings but rather in a universalizing fashion in the sense of the bonum commune humanitatis (KOTZUR, 2008, p. 265; PIAZOLO, 2004, p. 78-80), inasmuch as basic legal documents mention human beings or , more generally, make use of the word "all" (Art. I of Universal Declaration of Human Rights, Article 1, Article 2, 1, Article 3, 1, of the Charter of Fundamental Rights of the European Union (UNIÃO EUROPEIA. Carta dos Direitos Fundamentais da União Europeia); Art 1,1 and 2 of the American Convention on Human Rights (CONVENÇÃO AMERICANA SOBRE DIREITOS HUMANOS). 
The terms used in international document texts are general descriptions of the human being, without inferring, at first, nationality differentiation. Thus, humans are protected, regardless of their status of being, for instance, Brazilian or European. In spite of the fact that there are nationality differences throughout normative texts, the generality of the texts ensures the essential and existential minimum to any human being who is related to the participating State in these international documents, regardless of nationality.

Social rights are standardized and guaranteed in the EU member State constitutions as well as in the Brazilian Constitution ${ }^{15}$. Some Magna Cartas express social rights in a more general way; others, more specifically (ILIOPOULOS-STRANGAS, 2010. p. 746). Altogether, before human dignity, social rights are fundamental rights without which the modern sense of the Constitution would be weakened (VORLÄNDER, 2009 , p. 13). These are achievements that throughout history have ensured the human being protection against the State, which is the guarantor of these rights, and is considered an offender when silent, as well as legal and social obligations at the domestic, constitutional and international levels.

Internationally, the Universal Declaration of Human Rights should be considered a legal instrument with jus cogens quality ${ }^{16}$. It deals with the basic rights of every human being, informing States of their limitations and obligations to all those under their jurisdiction. Moreover, it is a normative paradigm for the international community since numerous treaties and conventions refer to it as a basis for their legislative platforms.

\subsection{The opening of the Brazilian Constitution to international law}

The Constitution of the Federative Republic of Brazil or Federal Constitution (FC) of 1988 is considered the legal sovereign document

\footnotetext{
15 Art. 5 of the Federal Constitution, which lists numerous fundamental rights and guarantees linked to negative freedom rights. Social rights are in other articles, mainly in Art. 6 and Art. 7 of the FC.

16 So is the interpretation of some legal experts, who believe that the passage from the domestic affair stage to the claim stage of the principle of international concern gives the Universal Declaration of Human Rights jus cogens status. (NETTO, 2010, p. 130-131; ANDRADE, 1987, p. 20).
} 
of the Brazilian State, and has two main openings - for the proposed theme - to international legal order. Art. 4 of the FC lists the principles by which international relations which Brazil takes part in will be guided. Altogether there are ten items, though the relevant ones for this study are: (a) national independence; (b) prevalence of human rights; (c) peoples' self-determination; (d) equality among States; (e) defense of peace; (f) cooperation among peoples for the progress of humanity.

Art. 4 of the FC is supplemented by Art. 5, §2 and §3. § 2, in fine, states that the rights and guarantees expressed in the $\mathrm{FC}$ do not exclude others adopted by international treaties of which Brazil is signatory. The text of $\S 3$ adds to both $\S 2$ and Art. 4, II of the FC ([2] prevalence of human rights) the relevance of human rights treaties and conventions, inasmuch as those treaties or conventions approved by the Congress - in two rounds of voting and by three fifths of the votes of its members - will have the status of constitutional amendments, i.e. constitutional rules. With Art. 4 of the Constitution and its guiding principles for Brazil action at an international level, and Art. $5, \S \S 2^{\circ}$ and 3 of the Constitution, the opening character of the FC to international human rights treaties and conventions in which Brazil participates becomes evident.

Consequently, the FC assigns central importance to human rights, reflected in the fundamental rights included in the FC text. This does not hold a declaratory significance alone, once Art. 5, paragraph 1 of the FC provides for the immediate application of provisions defining fundamental rights. Doctrinal and jurisprudential consecrated understanding indicates that the immediate implementation of fundamental rights involves all fundamental rights dimensions (SARLET, 1998, p. 85-87; 236). Therefore, both Freedom Rights and social rights have the same enforceability, that is, they are subjective rights ${ }^{17}$, independently of any need of normative complementation to the Constitution and, within

17 Some social rights have limited autonomous effectiveness as subjective right, since they require legislative action. However, their effectiveness is required in cases of violation of their minimum content. In this case, the judiciary can be asked to determine, in the face of a real case, the implementation of Social Law. (ANDRADE, 1987, p. 170; SARLET, 1998, p. 273). 
possible interpretations and the limits of the principle of reserve as for the economic sphere relevance. (SARLET, 1998, p. 259-261). Thus, to ensure the realization of social rights, people can individually take legal action called writ of injunction (Art. 5, LXXI of the FC) ${ }^{18}$, or collectively take a direct unconstitutionality action by omission (Art. $103 \S 2$ of the FC) ${ }^{19}$, (SARLET, 1998, p. 239-240).

The fundamental rights system structured by the FC includes human being dignity in the core of the legal system, seeking a balance between freedom, equality and solidarity. Therefore, there is extensive provision of fundamental rights, including social rights, with multiple guarantees. The concern of the constitutional legislator in providing fundamental rights of immediate effect is evident, although there are different fields of application and a constitutional openness to new rights by the provision of a review clause (NETTO, 2010, p. 149).

Another constitutional device that opens the system is the caput of Art. 5 of the FC, though some considerations need to be made. The caput of Art. 5 of the FC literally expresses that fundamental rights should be restricted to Brazilians and foreigners residing in Brazil. Thus, the individual who is in Brazil without such qualifications would not be covered by any guarantees or fundamental rights. This implies a distinction that violates the Universal Declaration of Human Rights (Art. I, II and III) and the American Convention on Human Rights (Art. 1, 1 and 2). However, a Supreme Court decision (Habeas Corpus 94016 MC / SP 2008) states that being a human being suffices for an individual to have access to fundamental rights, independently of his being Brazilian or a foreign resident in the country.

18 In cases when an individual, by the absence of a regulatory norm, is unable to exercise constitutional rights and freedoms and the prerogatives inherent to nationality, sovereignty and citizenship, he or she can be benefited by the writ of injunction.

19 This action can only be proposed by specific representative bodies and has the purpose of denouncing the omission of the subconstitution legislator or civil service for the lack of a regulatory provision that enables the effectiveness of the constitutional norm. In case of legislator omission, the Federal Supreme Court (FSC) will notify the legislature of the decision declaring the omission. If it is an omission by the public administration, 30 days from the notification will be given to rectify the omission declared by the Supreme Court. 
The opening of the Brazilian Constitution reflects a constitutional State which is open to the international and cooperative scene when taking into account international and supranational law influence. Such constitutional requirements, while keeping sovereignty and selfdetermination, demonstrate the existence of a space of interaction and absorption of international standards for human rights. (MARTINO, 2010, p. 272-273; 294-298). In this sense, Brazil declares and assumes its intention to participate in international relations also with regard to the support of Human Rights supportworldwide.

\section{Union possibilities between Brazil and the European Union}

The implementation of solidarity in the realization of social rights between Brazil and the European Union depends, among others, on economic, political and legal factors ${ }^{20}$. Its legal aspect is the object of reflection of this paper. This analysis has to take into account the Brazilian constitutional law and the law in force in the European Union Treaty (EUT), particularly changes brought by the Lisbon Treaty.

The kind of normative regulations between Brazil (a sovereign individual State) and the European Union (a legal community of sovereign States) that may give rise to the duty (principle) of solidarity between two distinct international realities as to social rights is a real obstacle. However, a possible solution to this issue is to be found in different normative dimensions of law. The first dimension is the sphere of customs. Both Brazil and EU countries maintain good diplomatic relations and are culturally close in many ways, considering different peculiarities on both sides. The second dimension covers statutory laws of each reality, once both Brazil and the EU share the same core universal and indivisible values in legal documentation: human dignity, freedom, equality, solidarity and civil rights, among others (PIAZOLO,

20 See Archiv des Völkerrecht, Band 52, Heft 1, März 2014. 
2004, p. 258). The third dimension is the Brazil and the EU countries commitment to the UN.

Given these dimensions, the proposed background for reflection is the constitutional law sphere which is open to international law (KOTZUR, 2008, p. 271 ${ }^{21}$, supported by the Universal Declaration of Human Rights, Art. VI, which states that every human being should be recognized as a person before the law (COMPARATO, 2001, p. 231). Through the strength of State sovereignty (as a unit and as a community member), we aim to use both rules and constitutional principles, and legal rules of the European Union. From this perspective, State sovereignty should not hinder the realization of social rights in the international or transnational law scene, but rather be an essential element towards essential aspects for the realization of social rights.

One should take into consideration that the Brazil and the European Union follow the semantics of the United Nations Charter, and consequently the various treaties proclaimed by the United Nations [UN] (Art. 3, 5, in fine, Art. 21 of the EUT) (UNIÃO EUROPEIA. Tratado da União Europeia (versão consolidada). It is a normative bond, i.e. prescriptive and declarative, and common (MARTINO, 2010, p. 342343), whose solidarity lies in the international legal order. (KOTZUR; SCHMALENBACH, 2014, p. 74). Thus, the two different international legal realities have common purposes, which are established in their legal rules. Furthermore, in terms of supranational instrumentation for the supra-State protection of human rights, regionalization of rights establishes a geopolitical perspective beyond State citizenship, also pursuing the utopian idea of cosmopolitan citizenship (PISANÒ, 2011, p. 53).

As for the regionalization of human rights, Brazil participates in the Covenant of Human Rights of San José, Costa Rica ${ }^{22}$, and follows

\footnotetext{
21 This is complemented by the prospect of constitutionalism - and also regional and international law -as being a cultutal acquisition par excellence, as emphasized by Häberle (2009, p. 64-65).

22 Decree 678/1992 expressed Brazil's adherence to the American Convention on Human Rights (Pact of San José, Costa Rica), held in 1969. <www.planalto.gov.br/ccivil_03/decreto/D0678. htm>. Site consulted on 17/11/2015.
} 
the Inter-American Court of Human Rights, in the same way as the European Union has its treaties concerning human rights and its own regional jurisdiction, the European Court of Human Rights. However, the jurisdiction of the Court of Justice of the European Union (CJEU) on EU countries is binding, in that effects can be imposed to EU States to some extent; whereas the Inter-American Court of Human Rights does not have the same jurisdictional effectiveness.

\subsection{Common norms / normative values}

Der Mensch gilt so, weil er Mensch ist, nicht weil er Jude, Katholik, Protestant, Deutscher, Italiener usf. Ist. (Hegel, §209, Grund. Phil.Recht)

Among similarities between Brazil and the EU, there is an inclination of these two international realities towards the Social State of Law value, which includes the social justice value in its normative basis, as it seeks social or individual welfare without distinction. Together with the idea of social justice, it also promotes individual justice upon ensuring the mediation between negative freedom rights and equal (or social) rights (VIDAL NETO, 1979, p. 165). (GIUFFRE, 2002, p. 232-233; PISANÒ, 2011 , p. 17-18). Freedom rights are exercised to the fullest when social rights can guarantee the existential minimum of material conditions through a fair distribution and redistribution of existing goods (SARLET, 1998, p. 202) by common effort. All efforts towards fundamental rights and human rights lead to the principle of human dignity, a core value in the Brazilian Constitution (Art. 1, III of the FC) and the European Union legal order (Art. 2 of the EUT) (UNIÃO EUROPEIA. Tratado da União Europeia (versão consolidada). Solidarity can be found in this context through mutual assistance requirements in economic, political and social terms through the distribution of advantages and disadvantages in the political association to achieve the purpose of common welfare to all (GIUFFRĖ, 2002, p. 24-25; KOTZUR; SCHMALENBACH, 2014, p. 74), thus creating a balance between freedom and equality (STRENGER, 2006, p. 983). 
The dignity of every human being is the basis for legal rules, preventing other legal rules to contradict their own rationale. Such an idea is neither an abstraction nor an ideality, but rather a reality expressed by legal rules which, anchored by an international (consensus omnium gentium) (PISANO, 2011, p. 27) ${ }^{23}$ and social consensus is projected into legal consciousness (ANDRADE, 1987, p. 41; MARTINO, 2010, p. 332-333). Human dignity is the source of all values linked to humans (COMPARATO, 2001, p. 228). From the paradigm of legal principles, it is possible to project an existential minimum into concrete life in order to establish basic human dignity limits. Thus, the international community, especially Brazil and the European Union ${ }^{24}$, has common value standards at constitutional and community levels which assign duties so that States can undertake actions to ensure the effectiveness of fundamental rights to both individuals and groups (MARTINO, 2010, p. 334; KOTZUR; SCHMALENBACH, 2014, p. 81).

Therefore, solidaritytakesanimportantnormativeandhermeneutical role before constitutional law and European Community legal dimensions. Solidarity aims to consolidate social rights, as a subjective legal situation within the institutional framework of organizational and financial nature (GIUFFRE, 2002, p. 103-104). It cannot be restricted to a normative universalization because of all political, legal and social difficulties, but a number of elements can be combined which, even in the face of culture, economic condition and social particularities (PISANÒ, 2011, p. 42), consider the human being a universal as well as a unique and concrete category. The characteristic of universality is found in the norms that offer the human being - and the very fact of being - dignity and uniqueness ${ }^{25}$ (the concrete dimension), which is met by the realization of these norms

23 Regarding human rights, see Häberle (2009, p. 256).

24 The assimilation of the rights contained in the Universal Declaration of Human and Citizen Rights from the European eighteenth-century legal philosophy, whose influence gave birth to human rights. (PISANÒ, 2011, p. 62).

25 There is a worldwide tendency for human rights to maintain a statement status, coming into effect through the particularities of national law insofar as they are accepted. (PISANÒ, 2011, p. 4849). However, such being the case, admitting the inevitable absorption of human rights by the State or Community law so that they can be accomplished, something that has been declared unavailable and legally valid to all human beings is ultimately left to a political decision. The issue of sovereignty will be subject of further analysis. 
which, in short, are fundamental rights / human rights when they ensure the existential minimum and tackle social vulnerabilities (SCHOLZ, 2014, p. 55-56).

\subsection{International Social Law Application}

The international protection of human rights has led to the development of an international law turned towards the human being, whose purpose is to protect the rights of Man, even at a minimalist and essential level. This is so because Man is the center of a social world order and cannot exercise his fundamental freedoms without the help of the State (SARLET, 1998, p. 313). Various agreements, conventions, customs, resolutions and international treaties have highlighed the importance of defending and promoting human dignity in individual terms, and human dignity itself demands material resources at the risk of becoming an empty formula (SARLET, 1998, p. 292), especially with relation to those who lack basic resources.

The international trend to unify human rights categories, acknowledging their fundamental and complementary character in relation to other categories (HÄBERLE, 2009, p. 258; NETTO, 2010, p. 132), is emphasized. This becomes evident through international treaties and agreements which include a minimum requirement clause for the fulfillment of provided rights, without which law would be denatured, and these documents would just contain intentions and statements. Therefore, the rights contained in those treaties and agreements are thought to be non-derogable and must not be deprived of efficiency, compromising the essential core of law. Whether or not the duty of provision in the realization of law depends on the State, it must respect and fulfill what was internationally agreed upon and declared. An example of an agreement containing the principle of solidarity is the International Covenant on Economic, Social and Cultural Rights ${ }^{26}$. Such

26 This pact is aimed at the protection of classes or economically underprivileged social groups, demanding an active role from the State through public policies or governmental action programs so as to raise the quality of life of the most deprived in the work, social welfare, education, health and housing fields. (COMPARATO, 2001, p. 335-336; NETTO, 2010, p. 180-181). 
an agreement imposes precepts of distributive or proportional justice in relation to social charges according to requirements of each social stratum (COMPARATO, 2001, p. 337).

Hence, the Additional Protocol to the International Covenant on Civil and Political Rights guarantees citizens of States which have ratified it the right of presentation and complaint to the Committee of Human Rights on any violations of any of the rights recognized and guaranteed in the Covenant (Art. 1) (CANOTILHO, 2002, p. 514-515) ${ }^{27}$. Similarly, the international protection of social rights is supported by the International Covenant on Economic, Social and Cultural Rights through which member States shall report on measures adopted, aiming to ensure the rights recognized in the Covenant (Art. 17). The European Social Charter obliges member States to ensure fundamental social rights to European citizens (CANOTILHO, 2002, p. 515) ${ }^{28}$.

The realization of social rights at a supra-national level is the result of a political, social, economic and legal globalization movement where Brazil and EU member States, or the EU, should or can no longer act in isolation or restricted to themselves, due to reciprocal commitments and mutual responsibilities (KOTZUR; SCHMALENBACH, 2014, p. 82$)^{29}$ to the human being, whose dignity is universally considered. The consciousness expressed in legal texts - as well as in costumes - demonstrates the normative concern to offer a minimum of dignity to all human beings who are both in Brazil and in the EU, thus reducing their vulnerability (SCHOLZ, 2014, p. 58) through the realization of social rights.

Accordingly, realization occurs internally with regard to Brazil and the EU, but in a solidary fashion, since both solidarity and social rights

\footnotetext{
27 Protocolo Adicional ao Pacto Internacional Direitos Civis e Políticos. H:IDecreto Legislativo N ${ }^{\circ}$ 311, DE 2009 - Publicação Original - Portal Câmara dos Deputados.html. Acesso em: 22 nov. 2015.

28 Comparato (2001, p. 342); lliopoulos-Strangas (2010, p. 942). The extension of Social rights to EU outsiders, as well as EU member State constitutional particularities, will not be the focus of discussion in this paper, however, some of these social rights should be extended to all foreigners.

29 Kotzur $(2008$, p. 265; 271).
} 
intend to maintain the existential minimum in order to offer dignity to the human being; without this, the right to self-determination of peoples (Art. 1 of the Covenant on Economic, Social and Cultural Rights)

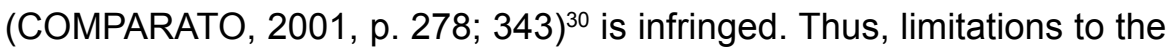
realization of social rights when these are restricted to qualified citizens only must be broken. Human dignity is not tied to the quality of citizenship, but rather applies to the human being as a concrete person. Solidarity specifically establishes a welfare policy (SCHOLZ, 2014, p. 61), without taking into account any qualifications or origin. The regionalization and globalization of human rights point to the need to change the relationship between State-citizen to State-human being.

Both people from the EU and Brazil should and can, according to what has been discussed so far in this article, find other ways to accomplish solidarity in the legal scope from Community law, international law (treaties), the Constitution and human rights references (KOTZUR; SCHMALENBACH, 2014, p. 84). The existential minimum must be extended to all and turn human dignity into a universalization element through solidarity in the sense of one another's acceptance (ZOLL, 2000 , p. 196). For such, the social framework of the legal system of Brazil and EU States has a duty to establish - so as to avoid neglect guarantees to an existential minimum, risk reduction (where possible) and growth stimulation (KOTZUR, 2008, p. 271). In this sense, three rights can be mentioned: 1) the right to assistance, even when it refers to the implementation of the existential minimum; 2) the right to access existing means to minimize the degree of disgrace; 3 ) the right to opt to change one's life ${ }^{31}$.

Solidary action should not be limited. The principle of solidarity requires co-responsibilities from both the one who acts in solidarity and the one who benefits from solidarity. Both parties must be sincere. The agent should show solidarity to its full, according to need, and

\footnotetext{
30 Iliopoulos-Strangas (2010, p. 942).

31 Such rights have been based on Kotzur (2008, p. 266).
} 
the beneficiary is expected to benefit to the exact extent of his need. Hence, upon implementing social rights through an act of solidarity, it is important to pose some paradigm questions: Who are the actors?; What is the point?; Which are the limits?; Which actions are legitimate? In other words: Solidarity with whom, why, what for, and how ${ }^{32}$. (PIAZOLO, 2004, p. 217).

Such paradigm questions, upon being answered, should set the parameters for common action and responsibilities involved in both action and factual circumstances. However, not all the answers to these questions will be valid and legitimate. Validity and legitimacy are to be found in responses focused on human dignity, that is, those containing normative values recognized by custom and governing laws at State, regional and international levels. For this reason, legal precepts to validate and legitimize solidarity actions should be evoked. Although Brazil and the EU are different legal institutions, have different stands in the international community scene and do not specifically keep a legal relationship which demands reciprocity in the treatment of their respective citizens in their territories, they share similar legal provisions, both in the Brazilian FC and the EUT. Also, both are one way or another linked to treaties and UN resolutions.

As for Law application by hermeneutics rules, the principle of human dignity coupled with fundamental and human rights meaning and normativity demands solidarity in the realization of social rights aimed at non-citizens. Indeed, the realization of Social rights, in this regard, will be limited according to the purpose of each Social Law. Legally speaking, this does not mean that citizens and non-citizens must be equalled, but rather they should be equipped with regard to the existential minimum maintenance of human dignity.

There are some examples to be followed by States in the international arena, such as Non-governmental Nonprofit Organizations

32 Was used as reference for the questions. 
(NGOs) which have established a network of caring people to work in various parts of the world in order to mitigate and report environmental violations (Greenpeace), assist in the medical field (Doctors Without Borders and the Red Cross), and Amnesty International, to mention a few. They are organizations which operate in locu through the solidarity of people who manage and finance them $(\mathrm{HONDRICH} ; \mathrm{KOCH}-$ ARZBERGER, 1992, p. 58) ${ }^{33}$. The central point of these parastatal organizations is that they do not distinguish territory, nationality or legal status of people who need help. They focus their solidarity actions on those in need and the very fact that they need help.

Brazil and the EU must admit that foreigners should be entitled to social rights accessibility, even if it is the essential necessary for their existence, regardless of their legal status in their territories. Such access to an essential minimum is performed by a duty of solidarity towards human beings, independently of their nationality. This is supported by the Brazilian CF and EU treaties, although in texts only citizens are entitled to these rights. However, the universal character of human dignity and human rights requires a non-restrictive interpretation in relation to the implementation of social rights so as to guarantee the existential minimum of every human being.

\section{Conclusion}

This text has proposed to establish a basis (among several possibilities) in order to justify the effectiveness of Social rights in international relations. Within the three possibilities given for a possible argumentative development, the relationship between State and foreigner (non-citizen) was chosen, on the assumption that the foreigner should have the right to an existential minimum and thereby be entitled to social rights - however limited they can be, as well as to those rights that can guarantee the maintenance of human dignity.

33 Piazolo (2004, p. 141). 
Upon establishing this assumption through the idea of solidarity and social rights, the verification of normative elements that could enable communication between the Brazilian and the European legal realities was sought, taking into account that they are two different magnitudes in the international political and legal scene. Therefore, we have tried to identify corresponding normative elements aimed at an international community composition involving only individual States, which nevertheless can also include regional State communities. This is a trend already observed within the economic relations of international markets.

Considering evaluative and normative parameters, there is a common core object of legal protection, which is human dignity. Such protection is developed from constitutions and treaties, declarations, customs aas well as regional and international resolutions. There are thus factors which lead to the common purpose of protecting humans. This aim is only tangible if pursued in solidarity between States and the international community. In this respect, there are normative and evaluative convergences which privilege human rights, independently of specific treaties or agreements between Brazil and the European Union. This is so because of the mutual recognition of human dignity and, therefore, the inevitability to guarantee the existential minimum to non-citizens.

\section{References}

ANDRADE, José Carlos Vieira de. Os direitos fundamentais na Constituição portuguesa de 1976. Coimbra: Almedina, 1987.

APOSTOLI, Adriana. La svalutazione del principio di solidarietà. Crisi di un valore fondamentale per la democrazia. Milano: Giuffrè, 2012.

ARENDT, Hannah. Origens do totalitarismo. Tradução Roberto Raposo. São Paulo: Companhia das Letras, 1989.

ARISTOTELES. Politik. Übers. Franz Susemihl. 3 Aufl. Hamburg: Rowohlts Enzyklopädie, 2010. 
BERCOVICI, Gilberto. Constituição econômica e desenvolvimento: uma leitura a partir da constituição de 1988. São Paulo: Malheiros, 2005.

BRASIL. Decreto n. 678/1992. Disponível em: <www.planalto.gov.br/ ccivil_03/decreto/D0678.htm>. Acesso em: 17 nov. 2015.

CANOTILHO, José Joaquim Gomes. Direito constitucional e teoria da constituição. 5. ed. Coimbra: Almedina, 2002.

CARTA DAS NAÇÕES UNIDAS. Disponível em: <unicrio.org.br/img/ Cartadaonu_Versolnternet.pdf>. Acesso em: 17 nov. 2015.

COMPARATO. Fábio Konder. A afirmação histórica dos direitos humanos. 2 ed. São Paulo: Saraiva, 2001.

CONVENÇÃO americana sobre direitos humanos. Disponível em: <www.oas.org/pt/cidh/mandato/Basicos/convencion.asp >. Acesso em: 17 nov. 2015.

CORTE Interamericana de Direitos Humanos. Resolução de 22 de maio de 2014. Disponível em: <http://www.corteidh.or.cr/docs/medidas/ curado_se_01_por.pdf>. Acesso em: 17 nov. 2015.

DEPENHEUER, Otto. Solidarität und Freiheit. In Handbuch des Staatsrechts der Bundesrepublik Deutschland. $(\mathrm{Hg})$ Josef Isensee und Paul Kirchhof. 3 Aufl. Band IX. Heidelberg: C.F.Müller, 2011. GIUFFRĖ, Felice. La solidarietà nell'ordinamento costituzionale. Milano: Giuffrè, 2002.

HÄBERLE, Peter. Verfassungsvergleichung in europa- und weltbürgerlicher Absicht. Später Schriften $(\mathrm{Hg})$ Markus Kotzur und Lothar Michael. Berlin: Duncker \& Humblot, 2009. HÖFFE, Otfried. A democracia no mundo de hoje. Tradução Tito Lívio Cruz Romão. São Paulo: Martins Fontes, 2005. 
HONDRICH, Karl Otto; KOCH-ARZBERGER, Claudia. Solidarität in der modernen Gesellschaft. Frankfurt am Main: Fischer Taschenbuch, 1992.

ILIOPOULOS-STRANGAS, Julia. Soziale Grundrechte in den Mitgliedstaaten der Europäischen Union im Rechtsvergleich unter Berücksichtigung des Europäischen Rechts. In: ILIOPOULOSSTRANGAS, Julia (Hrsg.) Soziale Grundrechte in Europa nach Lissabon. Eine rechtsvergleichende Untersuchung der nationalen Rechtsordnungen und des europäischen Rechts. Baden-Baden: Nomos, 2010. p. 699-1196.

KOTZUR, Markus Tobias; SCHMALENBACH, Kirsten. Solidarity Among Nations. Archiv des Völkerrechts. Band 52, Heft 1, März, Tübingen, 2014. p. 68-91.

KOTZUR, Markus. Soziales Völkerrecht für eine solidarische Völkergemeinschaft? Juristen Zeitung. 6. 63 Jahrgang, 21. März, Tübingen: Mohr Siebeck, 2008. p. 265-316.

LAFER, Celso. A reconstrução dos direitos humanos: um diálogo com o pensamento de Hannah Arendt. São Paulo: Companhia das Letras, 1988.

MARQUES, Mário Reis. A dignidade humana como prius axiomático. In: ANDRADE, Manuel da Costa; ANTUNES, Maria João; SOUSA, Susana Aires de. Estudos em Homenagem ao Prof. Doutor Jorge de Figueiredo Dias. Coimbra: Coimbra Editora, 2010. p. 541-566.

MARTINO, Alessandra di. II territorio: dallo stato-nazione alla globalizzazione: sfide e prospettive dello stato costituzionale aperto. Milano: Giuffrè, 2010.

VIDAL NETO, Pedro. Estado de Direito. Direitos individuais e direitos sociais. São Paulo: LTr, 1979.

NETTO, Luísa Cristina Pinto e. O princípio de proibição de retrocesso social. Porto Alegre: Livraria do Advogado, 2010. ORGANIZAÇÃO DAS NAÇÕES UNIDAS. Declaração Universal dos Direitos Humanos. Disponível em: <http://www.dudh.org.br/wpcontent/uploads/2014/12/dudh.pdf>. Acesso em: 15 nov. 2015. 
PIAZOLO, Michael. Solidarität. Deutungen zu einem Leiprinzip der Europäischen Union. Würzburg: Ergon, 2004.

PISANÒ, Attilio. I diritti umani come fenomeno cosmopolita. Internazionalizzazione, regionalizzazione, specificazione. Milano: Giuffrè, 2011.

PROTOCOLO ADICIONAL AO PACTO INTERNACIONAL DIREITOS CIVIS E POLÍTICOS. DECRETO LEGISLATIVO N³11, DE 2009 - Publicação Original - Portal Câmara dos Deputados.html. Disponível em: < http://www2.camara.leg.br/legin/fed/decleg/2009/ decretolegislativo-311-16-junho-2009-588912-publicacaooriginal113605-pl.> Acesso em: 22 nov. 2015.

RÜFNER, Wolfgang. Leistungsrechte. In: MERTEN, Detlef; PAPIER, Hans-Jürgen (Hrsg.) Handbuch der Grundrechte in Deutschland und Europa. Band II. Heidelberg: C.F. Müller, 2010.

SARLET, Ingo Wolfgang. Eficácia dos direitos fundamentais. Porto Alegre: Livraria do Advogado, 1998.

SCHOLZ, Sally J. Solidarity as a Human Right. Archiv des Völkerrechts. Band 52, Heft 1, März, Tübingen, 2014. p. 49-67.

SOMMERMANN, Karl-Peter. Some Reflections on the Concept of Solidarity and its Transformation into a Legal Principle. Archiv des Völkerrechts. Band 52, Heft 1, März, Tübingen, 2014. p. 10-24.

STOLZ, Erwin. Solidarity in Times of Crisis from a Sociological Perspective: A Comparative Analysis of Intergenerational Support in six European Countries. Archiv des Völkerrechts. Band 52, Heft 1, März, Tübingen, 2014. p. 113-136.

STRENGER, Georg. Philosophie der Interkulturalität. Erfahrung und Welten. Freiburg/München: Karl Albert, 2006.

UNIÃO EUROPEIA. Carta dos Direitos Fundamentais da União Europeia. Disponível em: <eur-lex.europa.eu/legal-content/PT/TXT/ PDF/?uri=CELEX:12012P/TXT\&from=PT>. Acesso em: 15 nov. 2015.

UNIÃO EUROPEIA. Tratado da União Europeia (versão consolidada). Disponível em: <http://eur-lex.europa.eu/legal-content/ 
PT/TXT/PDF/?uri=CELEX:12012M/TXT\&from=PT>. Acesso em: 15 nov. 2015.

VORLÄNDER, Hans. Die Verfassung. 3 Aufl. München: Beck, 2009. ZOLL, Reiner. Solidarität heute?. Frankfurt am Main: Suhrkamp, 2000.

Recebido em: 29/07/2016

Aprovado em: 14/03/2017 